\title{
ASSESSMENT OF Ips sexdentatus POPULATION CONSIDERING THE CAPTURE IN PHEROMONE TRAPS AND THEIR DAMAGES UNDER NON-EPIDEMIC CONDITIONS
}

\author{
PROCJENA POPULACIJE Ips sexdentatus S OBZIROM \\ NA ULOV U FEROMONSKIM KLOPKAMA I NJIHOVE \\ ŠTETNOSTI U NE-EPIDEMIJSKIM UVJETIMA
}

Gonca Ece ÖZCAN*

\begin{abstract}
Summary
one of the most important factors of natural balance in the forests are insects, which are a part of ecological diversity. Being in a constant change, forest ecosystems are affected by bark beetles in low level or wide ranged ratios. The pressure of Ips sexdentatus, one of the most important pests of conifer forests and principal species of Turkey, can be at a sensible level from time to time. In this study, it was determined that the beetles carry out two flights in the region, first flight starts around the beginning of May, this period continues until mid-June, second flight starts around mid-June and continues until the beginning of September. The number of beetles captured by the traps in the first and second flight period were statistically different and, also the average number of beetles in first period were more than second period. When the results of pheromone trap capturing were evaluated monthly, it was seen that the averages of June, July and August were not statistically different, meanwhile May average was statistically different from other months. No significant difference were found between the averages of I. sexdentatus captured by the pheromone traps in sunny and shaded aspect. No dying due to beetle damage was found on the trees in the study area after the flight of beetles, however, the damage ratio of the beetle was identified as $16.38 \%$ in a hectare. A statistically significant difference was found between the specified diameter classes in terms of beetle damage.
\end{abstract}

KEY WORDS: bark beetle, Ips sexdentatus, damage, pheromone trap, population density

\section{INTRODUCTION}

UVOD

Of the important components of forest ecosystem, insects, vertebrates and disease-causing factors may damage trees, or even cause them to die. However, the positive contribution of these factors to decomposition, energy flow, carbon and food cycle are in levels which cannot be denied (Haack and Byler 1993; Black 2005). Some species of bark beetles, of the effective elements of ecosystem process (Raffa et al. 2015), are keystones of forest ecosystem (Byers, 2012). The tree deaths caused by these species (Pickett and White, 1985) are long term legacies left in the forests (Meddens et

*Assist. Prof. Dr. Gonca Ece ÖZCAN, Ph.D., Kastamonu University, Faculty of Forestry, Department of Wildlife Ecology and Management, 37150, Kastamonu, Turkey.

Corresponding author: goncaece@hotmail.com 
al., 2012). Ips species may attack live trees but they usually prefer broken, overturned (Birch, 1984), where they don't face host resistance, trees that are dead or about to die (Fettig et al., 2007) and cause woody materials to decomposition, playing a role beneficial to forest ecosystems (Allen, 1994). In most species, while causing damage in low degree or below economic damage threshold in forests, large outbreaks of natural species are important in terms of development and sustainability of forests (Black et al., 2010). Besides that, huge losses happening in conifer forests due to bark beetle outbreaks are expected (Franceschi et al., 2005) and since their invasions cover large forest areas, it is not possible to fully evaluate the development of these invasions (Samalens et al., 2007). The relations between functional ecosystem and these outbreaks are not yet fully explained (Samman and Logan 2000). However, the determination of population dynamics of these beetles is very important to develop control strategies and increase success (Jactel and Lieutier, 1987).

Some beetles in the Coleoptera order are considered as the most destructive forest insects. Especially Dendroctonus, Ips, Scolytus species can cause large number of tree deaths (Drooz 1985; Furniss and Carolin 1977). Wood and Bright (1992) reported that there were 5812 species of bark beetles in the world. Bark beetles have a wide host range, including conifer species (Birch, 1984). These species, considered especially the important pests of conifer forests (Reeve, 1997), have caused important losses in the forests of the world until today (Bakke, 1989). These pests are the most dangerous beetles, especially the forests of northern hemisphere (Allen 1994; Lee et al., 2007). Six-toothed pine bark beetle, Ips sexdentatus (Boerner) (Coleoptera, Curculionidae, Scolytinae), one of the bark beetle pests, is one of the most destructive beetles of European pine forests and has an extremely high distribution potential (Jactel and Gaillard, 1991). This beetle, having the potential to create many offsprings from a female, depending on the number of generations, is also one of the most dangerous beetles of the forests of Turkey (Beşceli and Ekici, 1969). I. sexdentatus is a natural species of Turkey (Öymen, 1992) and is a principal beetle species (Özkaya et al., 2010) of pine and spruce trees (Akkuzu and Guzel, 2015). This species was found in the areas of Pinus nigra, Pinus silvestris, Pinus brutia, Picea orientalis, Abies nordmanniana and Abies bornmülleriana in our nation (Defne, 1954; Beşceli and Ekici, 1969; Yüksel, 1996; Öymen, 1992; Selmi 1998). One of the natural species of Turkey, Pinus nigra Arnold, constitutes 21,6\% of nations existence of forest (Anonymous, 2014). It also has large forestation potential (Topacoglu, 2013). Taking an important place in Turkey in terms of forest areas, forestry activities and forestry economy, $64 \%$ of Kastamonu is covered with forests. This ratio is considerably above the ratio of Turkey's existence of forest to total surface area of the nation. When the pure coniferous stands are eva- luated in terms of tree species, stands constituted by black pines form about $28 \%$ of provincial forest area and about $67 \%$ in the pure coniferous stands (Anonymous, 2013; 2014; URL-1). Most of these forests are threatened by I. sexdentatus, which causes tree deaths in large areas in case of a large outbreak and plays a critical role in forest dynamics. In this study, the capture rates of I. sexdentatus to pheromone traps, capture times, flight periods and the effects of these to daily maximum and average temperatures, changes of capture ratios according to shaded and sunny aspects in the black pine stand were determined (êrcan et al., 2011). Also, the damage status evaluated that caused in the stand by the beetle species after the end of flight period in the same year. The findings that will be obtained as a result of this study will make important contributions for creating a projection against this beetle which carries risks that may cause disruption of a health ecosystem by causing large damage to wide areas, monitoring, taking measures, ensure success in control management and sustainable forestry management.

\section{MATERIALS AND METHODS MATERIJALI I METODE}

\section{Study area - Promatrano područje}

This study, carried out in the pure stands of Pinus nigra Arnold in 2014, was conducted in Kastamonu, located in the western Blacksea region of Turkey (Figure 1). No damage and death trees record caused by I. sexdentatus in the area within the borders of Gölköy Forest Sub-District Directorate. Average altitude of the area was $1015.6 \pm 36.4 \mathrm{~m}$, average slope was $14.6 \pm 8.6 \%$. According to increment items taken from a total of 61 trees, tree age was $15.6 \pm 2.0$ year and mean tree diameter was $16 \pm 3.5 \mathrm{~cm}$ in terms of total tree in sample plot.

\section{Data Collection - Prikupljanje podataka}

30 pheromone traps (Figure 2) placed in black pine stands, captured total of Ips sexdentatus and Thanasimus formicarius (L.) (Coleoptera: Cleridae) adult in the traps are materials used to determine the rate of capture, capture times and flight periods of adult I. sexdentatus. Jactel (1991) has suggested that effect time of pheromone dispenser is short and the attraction radius of these preparations for Ips sexdentatus adults cannot exceed $100 \mathrm{~m}$. Besides that, the traps being placed close to each other can affect the capture rates due to causing competition between the traps (Serez, 1987; Bacca et al., 2006).

Thus, the numbered traps were hanged at the heights of 1.3$1.6 \mathrm{~m}$ as to be $100 \mathrm{~m}$ apart from each other, representing the area, on $8^{\text {th }}$ May. Elevation, slopes and aspects of the traps were measured, which were placed by leaving at least 6-10 $\mathrm{m}$ distance from trees (Kesinalemdaroğlu, 1995). The first commercial pheromone dispenser was hanged to traps at the date of its placement, and these dispensers were renewed 
Figure 1. Location of study area Slika 1. Lokacija promatranog područja
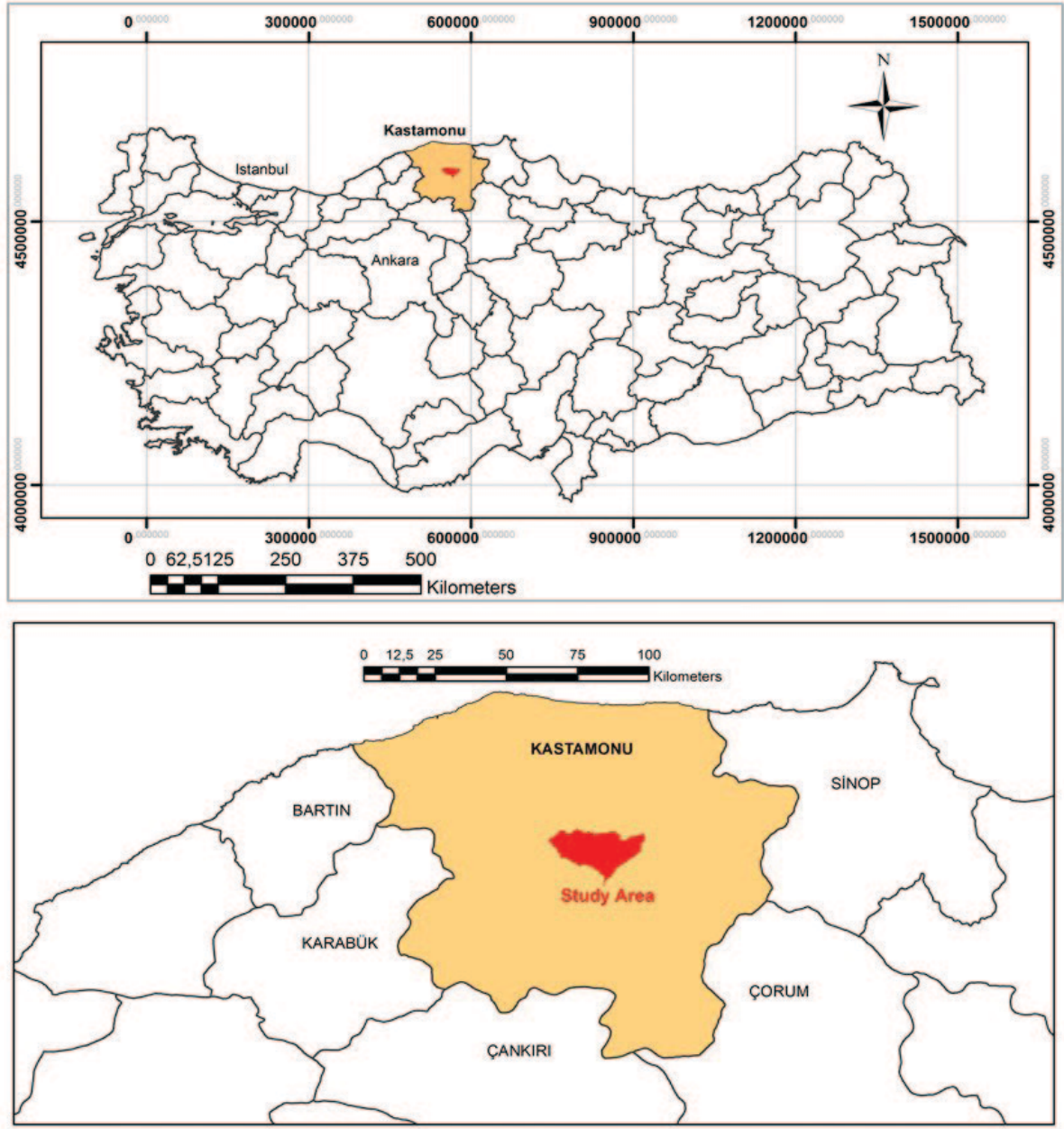

once every 6 weeks. Kept in the forest until $8^{\text {th }}$ of September, the traps were checked once every 7 days and a total of 570 counts were applied throughout 19 weeks, the number of $I$. sexdentatus and T. formicarius adults captured were recorded. Predator insects were taken to special boxes after counting and brought to $T$. formicarius breeding laboratory. Daily maximum and average temperature data of the study area were determined by interpolation from Kastamonu Meteorology Station. To determine the damage caused by I. sexdentatus after the end of flights, 458 black pine tree were evaluated in the 30 sample plots as large as $400 \mathrm{~m}^{2}$ in December of same year (Figure 2). Sample plots will be taken are randomly selected in stands where traps are placed. The borders of each sample plot was determined through tape measure and trees falling within the borders are numbered and their diameters are measured. Ages of 3 trees in each sample plot were determined. To identify the damage status and dying, dead trees, the trees were examined carefully.

\section{Statistical analyses - Statistička analiza}

All statistical analyses were performed using SPSS 20.0 for Windows' software. Independent samples t-test was used to determine whether the averages of I. sexdentatus captured by pheromone traps in sunny and shaded aspects in

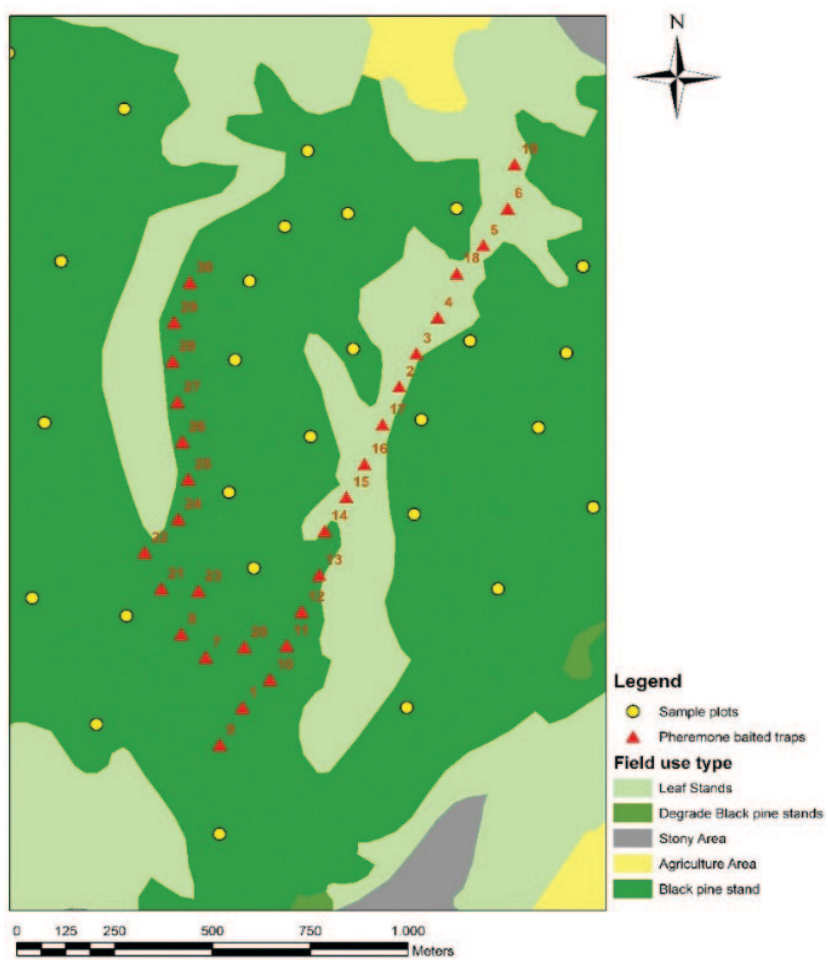

Figure 2. Locations of pheromone traps and sample plots in study area Slika 2. Lokacija feromonskih mamaca i uzorkovanih zemljišta na promatranom području 
both flight periods. The differences between the averages of I. sexdentatus captured to pheromone traps in 4 different months, which the capturing was carried out, were tested by one-way analysis of variance (ANOVA). Because the grouped data were used, the relations between trees which were damaged by I. sexdentatus and healthy and aspects and diameter classes were interpreted through Chi-Square test.

\section{RESULTS AND DISCUSSION REZULTATI I RASPRAVA}

Most common use of pheromones, preferred especially in monitoring aggressive forest pests (Bakke, 1991), are the evaluations depending on the number of beetles captured by traps (Suckling and Karg 2000). Mass trapping practices are being used for more than 200 years (Bakke, 1991) and this method is actively used in sustained forestry management practices in Turkey (Özcan et al., 2014). The reaction time given by $I$. sexdentatus individuals in a population varies. The effectiveness of pheromone traps (McNeil, 1991) and attraction capacity of the beetle to pheromone (Jactel, 1991) are affected by many factors (Bentz, 2006) such as stand attributes, wind direction, traps being hanged near suitable host trees (Safranyik et al., 2004), biology of the beetles, trap distance (Bacca et al., 2006), placement of traps and installation design (McNeil, 1991; Zahradník and Zahradníková, 2015). The ratio of capture of I. sexdentatus adults in traps at the edge and outside of the stand is higher than the traps inside the stand (Akkuzu and Güzel, 2015). Also, the population of beetles and the amount of beetles captured by traps vary by year and location (Özcan et al, 2011).
This research, 14556 I. sexdentatus and 608 T. formicarius were totally captured from using the pheromone traps. In the year the study was carried out, the average number of $I$. sexdentatus captured by the pheromone traps at the end of 19 weeks long monitoring process is $485.56,99 \%$ of these beetles were captured in 10 traps and the average capture amount of these traps are about 2,65 times more than the total number of beetles captured in traps. Özcan et al. (2011) determined that about $60 \%$ of the average number of beetles captured by traps are captured in certain number of traps. Pheromone traps are commonly used in monitoring of bark beetles population (Bentz, 2006). These monitoring help in obtaining data which may be utilized in various ways such as determination of flight activities and timing of control programs for target species (Suckling and Karg 2000). In the first controls performed with the traps in $8^{\text {th }}$ of May and last control performed in $8^{\text {th }}$ of September, considerably low capture ratios were recorded compared to other control periods. According to this, it is seen that flight activities of beetles start before $8^{\text {th }}$ of May and continue after $8^{\text {th }}$ of September and ratios being low and starting and ending dates of flight periods of beetles coincide approximately with these times (Figure 2). Although the conditions of the beetles at the time of capturing are unknown (Özcan et al., 2014), average daily temperature values at the time of first flight starting dates are approximately $11^{\circ} \mathrm{C}$, however, there are also days when the daily maximum temperature values are $20^{\circ} \mathrm{C}$ and above subsequently. It is expected that the beetles are captured in traps when the temperature conditions are suitable for their flight (Krieger, 1998). In the study explained by Seedre (2005), it is suggested that the first flight of the beetles is

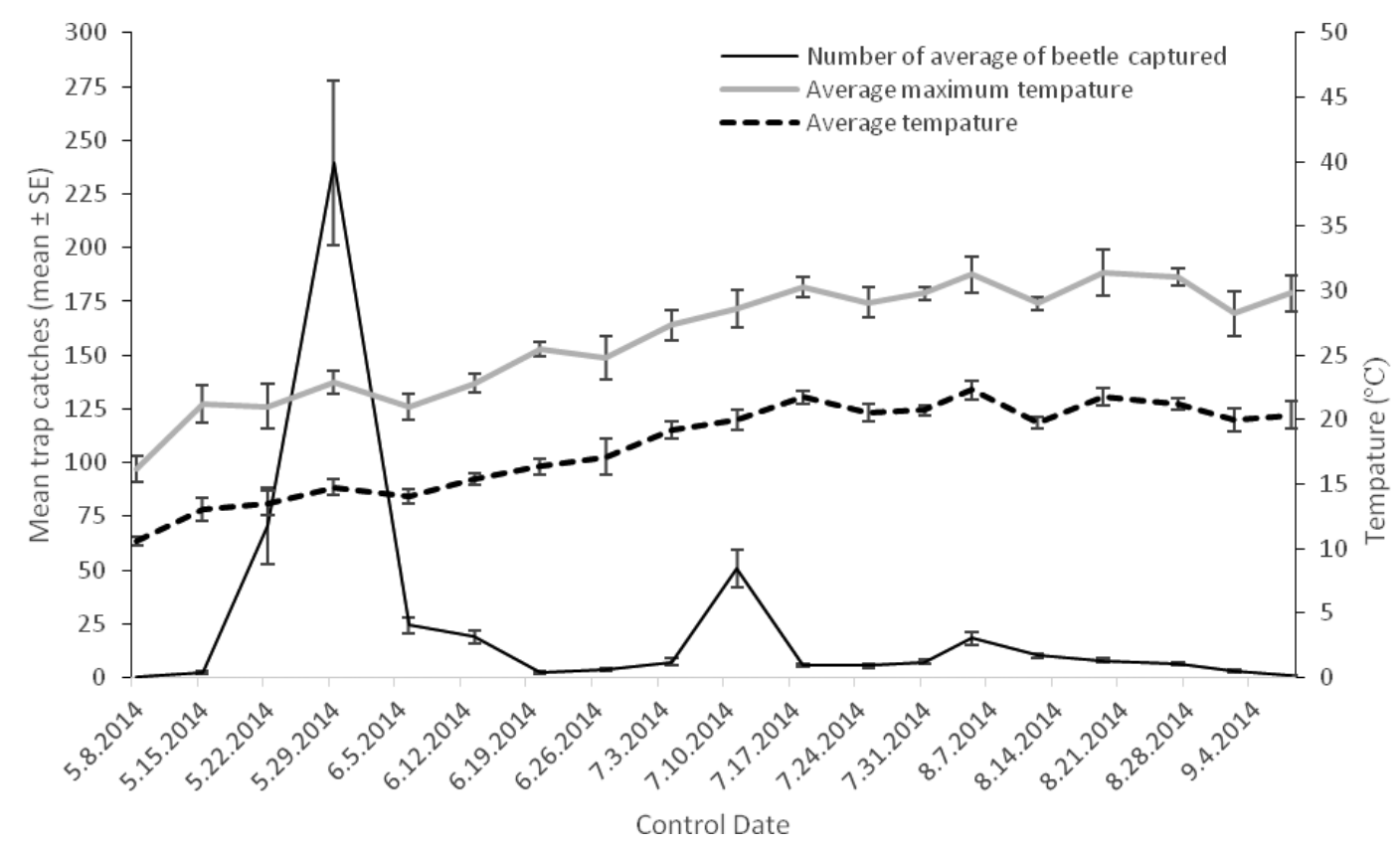

Figure 3. Capturing ratios of Ips sexdentatus to pheromone traps by control dates

Slika 3. Omjer hvatanja kukca Ips sexdentatus u feromonske mamce po kontrolnim datumima 
Table 1. Group statistics of Ips sexdentatus captured by traps in first and second periods

Tablica 1. Grupna statistika Ips sexdentatus uhvaćenih u mamcima tijekom prvog i drugog perioda

\begin{tabular}{|c|c|c|c|c|}
\hline $\begin{array}{l}\text { Periods } \\
\text { Periodi }\end{array}$ & $N$ & $\begin{array}{c}\text { Mean } \\
\text { Srednja vrijednost }\end{array}$ & $\begin{array}{l}\text { Std. Deviation } \\
\text { Std. devijacija }\end{array}$ & $\begin{array}{l}\text { Std. Eror Mean } \\
\text { Std. pogreška }\end{array}$ \\
\hline First periyod & 180 & 59,36 & 125,942 & 9,387 \\
\hline Second period & 390 & 9,93 & 19,362 & 0,980 \\
\hline
\end{tabular}

started at the times when the temperature values exceed about $20^{\circ} \mathrm{C}$, referred at Vité et al. (1974). Depending on these identifications, it can be said that I. sexdentatus carried out two flights in this period, first flight starts at early may, this period continues until mid-June and lasts about 40-45 days. Also, it can be said that second flight starts around mid-June and continues until early September and lasts about 50-55 days (Figure 3). However, it is not possible to differentiate the generation numbers and times of flight pe- riods with certain borders. With more extensive and long term studies, the status in the forests of the region may be detailed. Besides that, in a study covering two separate years carried out in the spruce forests, two generations of the beetle was reported and the dates given for two flight periods were approximately similar (Özcan et al., 2011). The findings of other studies on the number of generations of the beetle species and flight starting and ending times in Turkey (Beşceli and Ekici 1969; Serez, 1983, Sekendiz, 1984) and the findings of this study shows similarities.

$68.82 \%$ of the captured beetles are recorded in the controls applied in 22-29 May and 6 June and this time period falls within the first flight period specified. The average number of I. sexdentatus captured by traps in the first and second flight periods specified are 59.36 and 9.93, respectively (Table 1) and the difference in the I. sexdentatus captured between two periods are statistically significant $(p<0,05)$ (Table 2).

Table 2. Independent samples t-test results comparing the average number of beetles captured by traps in the first and second period Tablica 2. Neovisni uzorci rezultata t-testa kojima se uspoređuje prosječan broj kukaca uhvaćenih mamcima tijekom prvog i drugog perioda

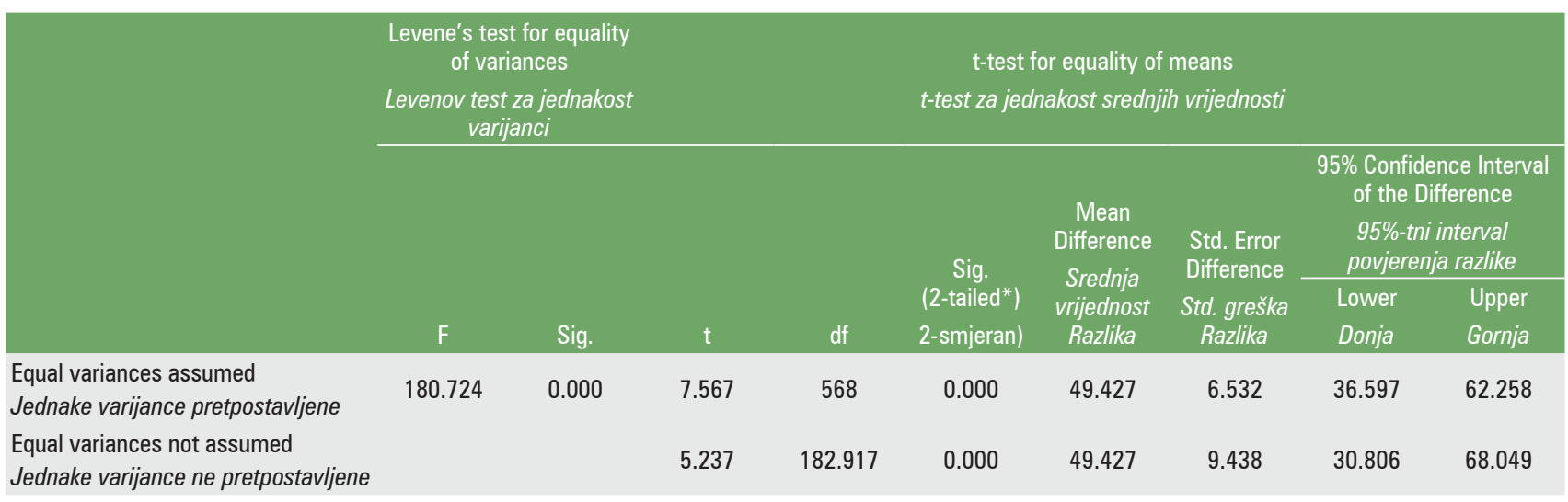

${ }^{*} \mathrm{p}<0,05$

Table 3. Resulting significant difference Turkey (HSD) test for the mean number of Ips sexdentatus by months Tablica 3. Rezultirajuće značajne razlike Tukeyeva (HSD) testa za srednji broj Ips sexdentatus po mjesecima

\begin{tabular}{|c|c|c|c|c|c|c|}
\hline \multirow{2}{*}{$\begin{array}{l}\text { (I) Months } \\
\text { (I) Mjeseci }\end{array}$} & \multirow{2}{*}{$\begin{array}{l}\text { (J) Months } \\
\text { (J) Mjeseci }\end{array}$} & \multirow{2}{*}{$\begin{array}{l}\text { Mean Difference (I-J) } \\
\text { Srednja razlika (I-J) }\end{array}$} & \multirow{2}{*}{$\begin{array}{l}\text { Std. Error } \\
\text { Std. greška }\end{array}$} & \multirow{2}{*}{ Sig. } & \multicolumn{2}{|c|}{$\begin{array}{l}95 \% \text { Confidence Interval } \\
95 \% \text { interval povjerenja }\end{array}$} \\
\hline & & & & & $\begin{array}{l}\text { Lower Bound } \\
\text { Donja granica }\end{array}$ & $\begin{array}{l}\text { Upper Bound } \\
\text { Gornja granica }\end{array}$ \\
\hline Maya & June $^{b}-$ Lipanj $^{b}$ & $65.833^{*}$ & 9.176 & 0.000 & 42.19 & 89.48 \\
\hline \multirow[t]{2}{*}{ Svibanja } & July ${ }^{\mathrm{b}}$ Srpanj & $62.937^{*}$ & 8.705 & 0.000 & 40.51 & 85.37 \\
\hline & Agustos $^{b}-K o l o v o z^{b}$ & $70.483^{*}$ & 8.376 & 0.000 & 48.90 & 92.07 \\
\hline June $^{b}$ & May $^{\mathrm{a}}-$ Svibanj $j^{\mathrm{a}}$ & $-65.833^{*}$ & 9.176 & 0.000 & -89.48 & -42.19 \\
\hline \multirow[t]{2}{*}{ Lipanj $^{b}$} & July ${ }^{\mathrm{b}}$ - Lipanj & -2.897 & 8.705 & 0.987 & -25.33 & 19.53 \\
\hline & Agustos $^{b}-K_{0}$ lovoz ${ }^{b}$ & 4.650 & 8.376 & 0.945 & -16.93 & 26.23 \\
\hline July ${ }^{b}$ & Maya - Svibanja & $-62.937^{*}$ & 8.705 & 0.000 & -85.37 & -40.51 \\
\hline \multirow{2}{*}{ Srpanj $^{b}$} & June $^{b}-$ Lipanj $^{b}$ & 2.897 & 8.705 & 0.987 & -19.53 & 25.33 \\
\hline & Agustos $^{b}-K_{0 l o v o z}$ & 7.547 & 7.858 & 0.772 & -12.70 & 27.79 \\
\hline August $^{b}$ & May ${ }^{\mathrm{a}}$ Svibanj ${ }^{\mathrm{a}}$ & $-70.483^{*}$ & 8.376 & 0.000 & -92.07 & -48.90 \\
\hline \multirow[t]{2}{*}{ Kolovoz ${ }^{\mathrm{b}}$} & June $^{b}-$ Lipanj $^{b}$ & -4.650 & 8.376 & 0.945 & -26.23 & 16.93 \\
\hline & July - Srpanj $j^{b}$ & -7.547 & 7.858 & 0.772 & -27.79 & 12.70 \\
\hline
\end{tabular}

\footnotetext{
* The mean difference is significant at the 0.05 level.
}

$a, b$ refers to different group 
Table 4. Group statistics of Ips sexdentatus captured by traps in sunny and shaded aspects

Tablica 4. Grupna statistika Ips sexdentatus uhvaćenih u mamce na suncu i u sjeni

\begin{tabular}{lcccc}
\hline $\begin{array}{l}\text { Aspects } \\
\text { Aspekti }\end{array}$ & N & $\begin{array}{c}\text { Mean } \\
\text { Srednja vrijednost }\end{array}$ & $\begin{array}{c}\text { Std. Deviation } \\
\text { Std. devijacija }\end{array}$ & $\begin{array}{c}\text { Std. Error Mean } \\
\text { Std. greška }\end{array}$ \\
\hline Sunny-Sunce & 342 & 27.60 & 83.346 & 4.507 \\
Shaded-Sjena & 228 & 22.44 & 63.436 & 4.201
\end{tabular}

When the trap capture results were evaluated as 4 separate months (which are May, June, July and August), it was seen that the averages of June, July and August were not statistically different $(p>0,05)$, mean while, the average for May was statistically different from other months $(\mathrm{p}<0,05)(\mathrm{Ta}-$ ble 3).

The average capture ratios for May is 6.32; 5.12 and 10.11 times higher than other months, respectively and according to this result, it is seen that spring captures are considerably higher than summer. In the study by Faccoli and Buffo (2004) for Ips typographus (Linnaeus), it was reported that spring captures are always higher than summer captures. Most bark beetle species' population intensity tend to increase and decrease according to weather conditions and existence of the host in their natural living habitat (Raffa et al. 2015).

Average temperatures in May, when the flights start, are between 10.55 and $14.77^{\circ} \mathrm{C}$, average maximum temperatures are between 16.13 and $22.91^{\circ} \mathrm{C}$. Daily maximum temperatures are sustainability to be important for the flight to begin and continue (Özcan et al., 2011). Gaylord et al. (2008), in the studies carried out various bark beetle species, has determined that maximum and average temperatures are more determinant than minimum temperatures in first flights. This determination supports the results of this study. Capturing more beetles in first flight period compared to second period may be due to traps capturing not only beetles in the effective region but also beetles coming from other regions (Jactel, 1991). Also, it is known that this species can fly 5-50 km distance and has the potential of easily going to farther distances where suitable hosts are available (Jactel and Gaillard 1991). It is believed that the population level of second generation is low due to many factors such as host trees being insufficient and climate conditions being unsuitable. 18 of the traps were placed at sunny and 12 at shaded aspects. The difference between the average number of I. sexdentatus captured in traps in sunny and shaded aspects is not statistically significant $(p>0.05)$. But, the number of beetles captured by traps in shaded aspects are $18.73 \%$ less than the sunny aspects (Table 4 , Table 5). Özcan et al. (2011) has also found similar results. Also, Lobinger and Skatulla (1996) have reported that I. typographus was captured in higher rate in traps in south aspects than north aspects (Wermelinger, 2004).

During the whole flight period of I. sexdentatus, a total of 576 T. formicarius adults were recorded in the traps. They were seen to be always present in the traps in all control dates. Predator insect was encountered mostly in the controls made during 22-29 May. The average amount of predators captured by the traps at this time are 2.3-5.2, respectively. One of the main predators of I. sexdentatus, Thanasimus formicarius L (Coleoptera: Cleridae) (Seedre, 2005), is a predator of many bark beetle species (Warzee and Grégoire, 2003). Also, this predator is attracted to bark beetle pheromones (Schoreder, 1997).

Raffa et al. (2015) also suggests that stand structures are effective on the preferences of bark beetles. Accordingly, beetles that may cause severe tree deaths in one year by their outbreaks, can only cause deaths of live trees (Christiansen et al., 1987) when they cause an epidemic by increasing breeding potentials in other words, when their population reaches a level that exceed the resistance of the host (Drooz, 1985). In this study, it was identified that $19.65 \%$ of 458 trees evaluated in the sample plot covering 1.2 hectares of area were damaged by the beetle and accordingly, the damage rate in a hectare was $16.38 \%$ (Figure $4 a, b$ ), however, no de-

Table 5. Independent samples t-test results comparing the average number of beetles captured by traps in sunny and shaded aspects Tablica 5. Neovisni uzorci rezultata t-testa u usporedbi s prosječnim brojem kukaca uhvaćenih u mamce na suncu i u sjeni

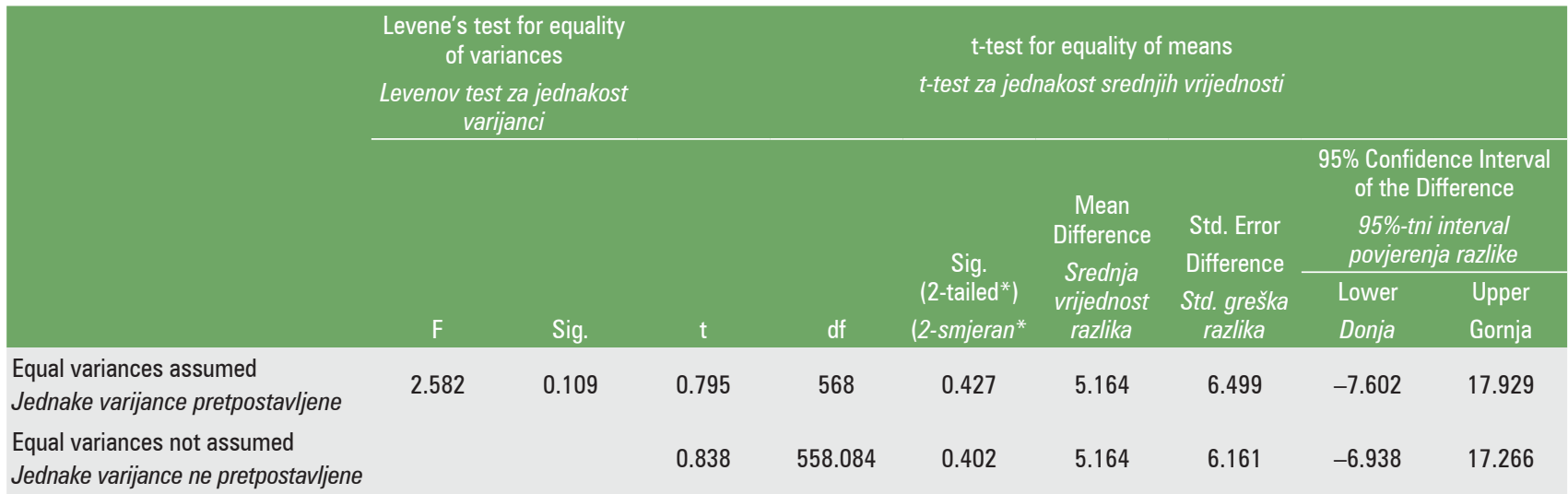


Table 6. Relations between trees damaged, undamaged by Ips sexdentatus and aspects Tablica 6. Odnos između oštećenih i neoštećenih stabala od strane Ips sexdentatus i aspekti

\begin{tabular}{|c|c|c|c|c|c|}
\hline \multirow{2}{*}{$\begin{array}{l}\text { Aspects } \\
\text { Aspekti }\end{array}$} & \multirow[t]{2}{*}{ N } & \multicolumn{2}{|c|}{$\begin{array}{l}\text { Undamaged trees } \\
\text { Neoštećena stabla }\end{array}$} & \multicolumn{2}{|c|}{$\begin{array}{l}\text { Damaged trees } \\
\text { Oštećena stabla }\end{array}$} \\
\hline & & $\bar{N}$ & $\%$ & $\mathrm{~N}$ & $\%$ \\
\hline North - Sjever & (168) & 138 & 82.14 & 30 & 17.86 \\
\hline South - Jug & (197) & 158 & 80.20 & 39 & 19.80 \\
\hline East - Istok & (43) & 33 & 76.74 & 10 & 23.26 \\
\hline West - Zapad & (50) & 39 & 78.00 & 11 & 22.00 \\
\hline Total - Ukupno & 458 & 368 & & 90 & \\
\hline
\end{tabular}

ath and dying tree was seen in the area. No death tree or damage caused by I. sexdentatus in the previous years was found out and no outbreak population of the beetle at a level causing trees to death were created during the year. These low level invasions occurring in stands where young and healthy individuals are present have the possibility of causing only damage.

The results obtained in this study shows parallelism with the results of studies on the damage levels of low level invasions. Samman and Logan (2000) emphasizes that the invasion of bark beetle occurring endemic levels causing less than $2 \%$ death rates of trees will be beneficial in terms of removing weak and old individuals from stands. Therefore the removal of damaged trees in the area in terms of forest health should be evaluated within the plans.

Of the tree evaluated in the sample plots are, respectively, $36.68 \%$ for north, $43.01 \%$ for south, $9.39 \%$ for east and $10,92 \%$ for west in aspects. The percentages of trees damaged by I. sexdentatus in the study area according to aspects are $33.33 \%, 43.34 \%, 11.11 \%$ and $12.22 \%$, respectively. Despite no significant difference was found between the trees damaged and undamaged by beetles according to aspects ( $>0.05$ ), (Table 6) it was determined that the trees damaged by beetle was found highest in the south aspects (43.34\%).
Table 7. Relations between trees damaged, undamaged by Ips sexdentatus and diameter lasses

Tablica 7. Odnos između oštećenih i neoštećenih stabala od strane Ips sexdentatus i klasa po promjeru

\begin{tabular}{lccccc}
$\begin{array}{l}\text { Diameter classes }(\mathrm{cm}) \\
\text { Po promjeru }(\mathrm{cm})\end{array}$ & $\mathrm{N}$ & $\begin{array}{c}\text { Undamaged trees } \\
\text { Neoštećena stabla }\end{array}$ & \multicolumn{2}{c}{$\begin{array}{c}\text { Damaged trees } \\
\text { Oštećena stabla }\end{array}$} \\
\cline { 2 - 6 } $8-12$ & & $\mathrm{~N}$ & $\%$ & $\mathrm{~N}$ & $\%$ \\
$12-16$ & $(33)$ & 28 & 82,85 & 5 & 15,15 \\
$16-20$ & $(130)$ & 112 & 86,15 & 18 & 13,85 \\
$20-24$ & $(173)$ & 146 & 84,40 & 27 & 15,60 \\
Total & $(122)$ & 82 & 67,21 & 40 & 32,79 \\
& 458 & 368 & & 90 &
\end{tabular}

$\chi^{2}=18,322, d f=3, p<0,05$

Diameter of the trees in sample plots are; 33 of them (7.21\%) at $8-12 \mathrm{~cm}, 130$ of them $(28.38)$ at $12-16 \mathrm{~cm}, 173$ of them $(37.77 \%)$ at $16-20 \mathrm{~cm}$ and 122 of them (26.64\%) at 20-24 $\mathrm{cm}$. There is a statistically significant difference between the diameters classes specified in terms of beetle damage $(\mathrm{p}<0.05)$ (Table 7) and it is seen that trees in diameter classes $20-24 \mathrm{~cm}$ are exposed to beetle damage more than others. $44.44 \%$ of the damaged trees are in this diameter classes (Figure 5).

Although the management strategies of bark beetles are not planned as to completely remove their populations due to

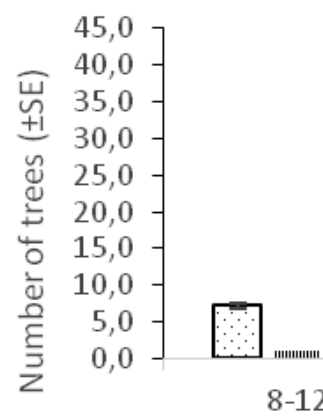

8-12
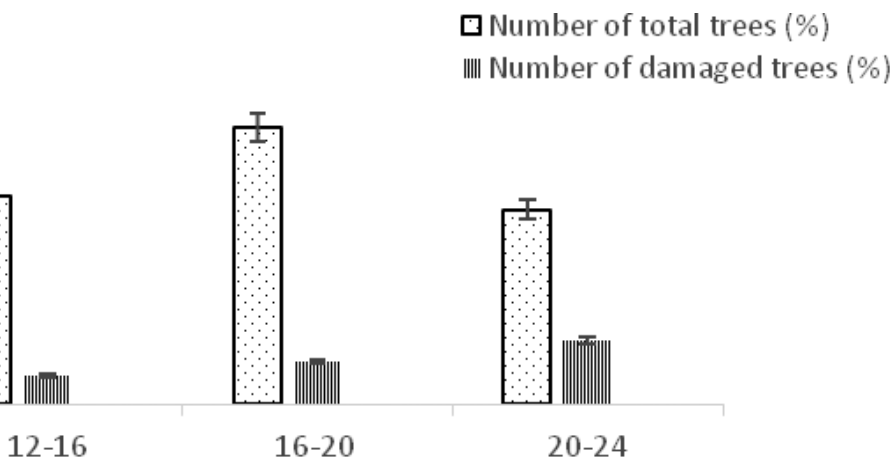

Diameter classes $(\mathrm{cm})$

Figure 5. Distribution of total and damaged trees in the sample plots according to diameter classes Slika 5. Distribucija ukupnih i oštećenih stabala na uzorkovanim zemljištima prema klasama po promjeru 
their roles in the ecosystem process (Samman and Logan 2000), it is a requirement to suppress their outbreak populations. The purpose of control programs planned against these species is to effectively reduce their damage levels in the stands (Faccoli and Stergulc, 2008). Removing weak and damaged trees found in the area before the population density of I. sexdentatus, which is a pest, reaches to a level that will attack healthy trees, including trees that are slightly injured or healing, will decrease the dying risk of healthy trees (Fernández Fernández, 2006). Bark beetle invasions start in damaged and/or stressed trees (Douce, 1998). Long term disturbances causing stress in tree may lower the resistance of trees, and therefore trees may become sensitive even in low beetle densities (Power et al., 1999). Stressed trees are more sensitive to I. sexdentatus attacks. For this reason, in forest areas where fire or wind weakened trees are present, beetle attacks may be more (Seedre, 2005).

In light of the explanations, in a healthy ecosystem where natural balance is preserved; utilizing our forests through sustainable planning is one of the main principles of today's forestry. In these planning, bark beetles, one of the factors that has the potential to cause high damage, causing unplanned cutting in cases of outbreaks and therefore threatening our forests, is important in terms of forestry. In the black pine forests, which has important propagation through stands they form in Turkey, explaining the flight periods, capturing rates and some factors affecting the capturing of I. sexdentatus and understanding the damage the species may cause in endemic levels will contribute to increasing effectiveness of control programs to be carried out.

\section{REFERENCES}

\section{BIBLIOGRAFIJA}

- Akkuzu, E., Guzel, H., 2015: Edge effects of black pine forests on Ips sexdentatus (Boern.) abundance, Šumarski list, 9, 10, 447453.

- Allen, D.C., 1994: The bark beetles. NY Forest Owner. 27-2p.

- Anonim, 2013: Orman Atlası. T.C. Orman ve Su İşleri Bakanlığı Orman Genel Müdürlüğü, Bilgi Sistemleri Dairesi Başkanlığı, Coğrafi Bilgi Sistemleri Şube Müdürlüğü. 107 p., Ankara

- Anonim, 2014: Türkiye orman varlığı, Yayın No: 15, Envanter Seri No: 17. T.C. Orman ve Su İşleri Bakanlığı Orman Genel Müdürlüğü, Orman İdaresi ve Planlama Dairesi Başkanlığı, 25 p., Ankara.

- Baca, T., Lima, E.R., Picanço, M.C., Guedes, R.N.C., Viana, J.H.M., 2006: Optimum spacing of pheromone traps for monitoring the coffee leaf miner Leucoptera coffeella. Journal compilation Netherlands Entomological Society. Entomologia Experimentalis et Applicata, 119, 39-45.

- Bakke, A., 1989: The recent Ips typographus outbreak in Norway-experiences from a control program. Holarctic Ecology, 12: 515-519.

- Bakke, A., 1991: Using pheromones in the management of bark betlee outbreaks. Baranchikov, Y.N., Mattson, W.J., Hain, F.P. and Payne, T. L., eds.1991. Forest Insect.371-377. Guilds: Patterns of Interactionwith Host Trees. U.S. Dep. Agric. For. Serv. Gen. Tech. Rep. NE-153.

- Black, S.H., 2005: Logging to control insects: The science and myths behind managing Forest Insect „Pests”. A synthesis of independently reviewed research. pp 45.

- Black, S. H., Kulakowski, D., Noon, B.R., DellaSala, D., 2010: Insects and roadless forests: A scientific review of causes. Consequences and management alternatives. National Center for Conservation Science, p 33.

- Bentz, B.J., 2006: Mountain pine beetle population sampling: inferences from Lindgren pheromone traps and tree emergence cages. Canadian Journal of Forest Research, 36: 351-360

- Besceli, O., Ekici, M., 1969: Dogu Ladini (Picea orientalis L.) mintikasinda Ips sexdentatus'un biyolojisi ve mucadelesi. Ormancılık Aras. Ens. Yayınl., Teknik Bülten Ser. No. 32, p. 32.

- Birch, M., 1984: Aggregation in bark beetles. In: Bell, W.J., Carde, R.T. (Eds.). Sinauer Associates, Shutherland, Mass.

- Byers, J.A., 2012: Ecological interactions of bark beetles with host trees. Hindawi Publishing Corporation Psyche Volume 2012, Article ID 252961, doi:10.1155/2012/252961

- Christiansen, E., Waring R.H., Berryman A.A., 1987: Resistance of conifers to bark beetle attack: searching for general relationships. Forest Ecology and Management, 22, 89-10

- Douce GK. 1998. Pine Bark Beetles. The Entomology and Forest Resources Digital Information Work Group. Forest Landowner. 57:4 In Press.

- Defne, M., 1954: Ips sexdentatus (Boerner) Kabuk böceğinin Çoruh ormanlarındaki durumu ve tevlit ettiği zararlar. İ.Ü. Orman Fakültesi Dergisi, IV, II, 80-91.

- Drooz, A.T., 1985: Insects of Eastern Forests, USDA Forest Service, Misc. Pub. No. 1426. 608pp.

- Faccoli, M., Buffo, E., 2004: Seasonal variability of sex-ratio in Ips typographus (L.) pheromone traps in a multivoltine population in The Southern Alps. Journal of Pest Science, 77, 123-129.

- Faccoli, M., Stergulc, F., 2008: Damage reduction and performance of mass trapping devices for forest protection against the spruce bark beetle, Ips typographus (Coleoptera Curculionidae Scolytinae). Annals of Forest Science, 65, 309p9.

- Fernández Fernández, M.M., 2006: Colonization of fire-damaged trees by Ips sexdentatus (Boerner) as related to the percentage of burnt crown. - Entomologica Fennica 17: 381-386.

- Fettig, C.J., Klepzig, K.D., Billings, R.F., Munson, A.S., Nebeker, T.E., Negron, J.F., Nowak, J.T., 2007: The effectiveness of vegetation management practices for prevention and control of bark beetle infestations in coniferous forests of the western and southern United States. Forest Ecology and Management, 238, 24- 53.

- Franceschi, R.V, Krokene, P., Christiansen, E., Krekling, T., 2005: Anatomical and chemical defenses of conifer bark against bark beetles and other pests. Tansley review. New Phytologist 167: 353-376.

- Furniss, R.L., Carolin, V.M. 1977: Western forest insects. USDA Forest Service, Misc. Pub. No: 1339, 654 p.

- Gaylord, M.L., Williams K.K., Hofstetter, R.W., Mcmillin,D., Degomez, T.E., Wagner, M.R. 2008: Influence of temperature on spring flight initiation for southwestern ponderosa pine bark beetles (Coleoptera: Curculionidae, Scolytinae). Environmental Entomology, 37(1): 57-69. 
- Haack, R.A., Byler J.W., 1993: Insects and pathogens, regulators of forest ecosystems. Journal of Forestry, 91, 9: 32-7.

- Jactel, H., Lieutier, F. 1987: Effects of attack density on fecundity of the Scots pine beetle Ips sexdentatus Born (Col: Scolytidae). Journal of Applied Entomology, 104:190-204.

- Jactel, H., 1991: Dispersal and fight behaviour of lps sexdentatus (Coleoptera: Scolytidae) in pine forest. Annales des sciences forestiéres, 48 (4), 417-428.

- Jactel, H., Gaillard, J., 1991: A preliminary study of the dispersal potential of Ips sexdentatus (Boern) (Col., Scolytidae) with an automatically recording flight mill. Journal of Applied Entomology, 112, 138-145

- Keskinalemdar, E., 1995. Ips typographus L. (Coleoptera, Scolytidae)'un Biyolojisi ve Mücadelesi Üzerine Araştırmalar, Ormancılık Araştırma Enstitüsü Yayınları, Teknik Bülten Seri No:246, Ankara, $40 \mathrm{~s}$.

- Krieger, C., 1998: An overview of bark beetle control methodologies. Forestry. Working Now For The Future. Management Notes. No:17, 8pp.

- Lee, J.C., Haack, R.A., Negrón, J.F., Witcosky, J.J., Seybold, S.J. 2007: Invasive bark beetles. Newtown Square, PA: Forest Insect and Disease. Leaflet 176.12pp. USDA Forest Service

- Lobinger, G., 1995: Einsatzmoglichkeiten von borkenkäferfallen. Allg. Forst. Z., Waldwirtsch, Umweltvorsorge, 50: 198201

- McNeil, J.N., 1991: Behavioral ecology of pheromone-mediated communication in mothd and its importance in the use of pheromone traps. Annual Review of Entomology, 36:406-430.

- Meddens, A.J., Hicke, J.A., Ferguson, C.A., 2012: Spatiotemporal patterns of observed bark beetle-caused tree mortality in British Columbia and the western United States. Ecological Applications, 22, 7, 1876-1891.

- Oymen, T., 1992: The forest scolytidae of Turkey. İ.Ü. Orman Fakültesi Dergisi, A, 42, I, 77-91.

- Özcan, G.E., Eroğlu, M., Alkan-Akınc1, H., 2011: Use of pheromone-baited traps for monitoring Ips sexdentatus (Boerner) (Coleoptera: Curculionidae) in oriental spruce stands, African Journal of Biotechnology, 10 (72): 16351-16360.

- Özcan, G.E., Cicek, O., Enez, K., Yıldız, M., 2014: A new approach to determine the capture conditions of bark beetles in pheromone-baited traps, Taylor \& Francis, Biotechnology \& Biotechnological Equipment, 2, 28, 6: 1057-1064.

- Özkaya, M.S., Aksu, Y., Göktürk, B.Ç., 2010: Investigations on biology, morphology, distribution, detriments and control efforts of Ips sexdentatus (Boerner) (Coleoptera: Scolytidea) damaged in Picea orientalis and Pinus silvestris forests. III. Ulusal Karadeniz Ormancilık Kongresi 20-22 May1s, IV, 1318-1326.

- Pickett, S.T.A., White, P.S. (Editors), 1985: The ecology of natural disturbance and patch dynamics. Academic Press, FL, 472 pp. Orlando.

- Power JS, Sollins P, harmon ME, Jones JA. 1999. Plant-pest interactions in time and space: A Douglas-fir bark beetle outbreak as a case study. Landscape Ecology. 14: 105-120.

- Raffa, K.E, Grégoire, J.C, Lindgren, B.S., 2015: Natural history and ecology of bark beetles. Bark beetles biology and ecology of native and invasive species. Elsevier. 1: 1-28

- Reeve, J. D., 1997: Predation and bark beetle dynamics. Oecologia. 112, 48-54.
- Safranyik, L., Shore, T.L., Linton D.A., 2004: Measuring trap efficiency for bark beetles (Col., Scolytidae). Blacwell Verlag, Jornal of Applied Entomology, 128, 5: 337- 341.

- Samalens, J.C., Rossi J.P., Guyon, D., Halder, V; Menassieu P, Piou, D., Jactel, H. 2007: Adaptive roadside sampling for bark beetle damage assessment. Forest Ecology and Management 253, 177-187.

- Samman, S., Logan, J., tech. (eds.) 2000: Assessment and response to bark beetle outbreaks in the Rocky Mountain area. Report to Congress from Forest Health Protection, Washington Office, Forest Service, U.S. Department of Agriculture. Gen. Tech. Rep. RMRS-GTR-62. Ogden, UT: U.S. Department of Agriculture, Forest Service, Rocky Mountain Research Station. 46 p.

- Seedre, M., 2005: Ips sexdentatus damage in Montesquiu Castle Park Scots Pine Stands; overview and management recommendations, applied period project report, Course „Master of European Forestry Erasmus Mundus. Supervised by Jordi Jürgens, 14 pp. Barcelona, Spain.

- Sekendiz, O.A., 1984: Ormanlarımızda önemli zararları görülebilen kabuk böcekleri Scolytidae (Ipidae) familyası türleri, koruma ve savaş yöntemleri. 16-22 Nisan, Orman Böcek ve Hastalıkları Seminer Notları. Antalya.

- Selmi, E., 1998: Türkiye kabuk böcekleri ve savaşı, İstanbul Üniversitesi Yayın No 4042, Emek Matbaacilık, 196p. Istanbul.

- Serez, M., 1983: Türkiye orman zararlı böceklerinden Ips sexdantatus (Boerner) savaşında ilk feromon denemeleri. KTÜ Orman Fakültesi Dergisi 2: 251-256.

- Serez, M., 1987: Bazı onemli kabuk bocekleriyle savasda feromonların kullanılma olanakları. KTU Orman Fakültesi Dergisi 10 (1): 99-131.

- Suckling, D.M., Karg, G., 2000: Pheromones and other semiochemicals. Rechcigl, J, E., Rechcigl N.A., Biological and biotechnological control of insect pests. CRC Press LLC, Lewis publishers, Baco Raton London, p. 63-99. New York Washington D.C.

- Topacoglu, O., 2013: Genetic diversity among populations in black pine (Pinus nigra arnold. Subsp. Pallasiana (lamb.) Holmboe) seed stands in Turkey. Agricultural Academy. Bulgarian Journal of Agricultural Science, 19 (6): 1459-1464

- Warzee, N., Grégoire, J.C., 2003: Thanasimus formicarius (Coleoptera, Cleridae) why a large range of prey for a specialized predator? Proccedings. IUFRO Kanazawa, Forest Insect Population Dynamics and Host Influences, p. 16-18.

- Wermelinger, B., 2004: Ecology and management of the spruce bark beetle Ips typographus - a review of recent research. Forest Ecology and Management 202: 67-82.

- Wood SL, Bright DE. 1992. A catalog of Scolytidae and Platypodidae (Coleoptera), part 2: Taxonomic index. Great Basin Naturalist Memoires. 13: 1-1553.

- Yüksel, B., 1996: Türkiyede Doğu Ladini (Picea orientalis) (L.) (Link.)'nde zarar yapan böcekler ve bazı türlerin yırtıcıve parazitleri üzerine araştırmalar, Doctoral Thesis, Karadeniz Technical University, Trabzon, Turkey.

- Zahradník, P., Zahradníková, M., 2015: The efficacy of a new pheromone trap setup design, aimed for trapping Ips typographus (Coleoptera, Curculionidae, Scolytinae). Sumarski list, 3-4, 181-186.

- URL-1 http://kuzka.gov.tr/Icerik/Dosya/www.kuzka.gov.tr_32_ WH6T47TP_415_orman_ ormancilik.pdf (Accesed 07 Jan 2015) 


\section{Sažetak}

Jedan od najvažnijih čimbenika prirodne ravnoteže u šumama su insekti, koji čine dio ekološke raznolikosti. Pod utjecajem stalnih promjena, šumski su ekosustavi pod utjecajem kukaca potkornjaka na niskoj razini ili velikom prostoru. Pritisak Ips sexdentatus, jedne od najvažnijih štetočina u crnogoričnim šumama te glavne vrste u Turskoj, može s vremena na vrijeme biti na osjetljivoj razini. Ovom je studijom otkriveno da kukci odrade dva leta u regiji, prvi let započinje početkom svibnja, nastavlja se do sredine lipnja, dok drugi započinje sredinom lipnja i nastavlja se do početka rujna. Broj uhvaćenih kukaca u mamcima tijekom prvog i drugog perioda leta bio je statistički različit, te je prosječan broj kukaca u prvom periodu bio veći od broja kukaca u drugom periodu. Kada su se rezultati uhvaćenih kukaca u feromonske mamce procijenili na mjesečnoj razini, uočilo se da nema statističkih razlika između lipnja, srpnja i kolovoza, dok se prosječan broj za svibanj statistički razlikovao od drugih mjeseci. Nije pronađena značajna razlika između prosjeka broja $I$. sexdentatus uhvaćenih feromonskim mamcima na suncu i u sjeni. Nije otkriveno odumiranje na stablima promatranog područja zbog štete od kukaca nakon njihova leta, no, identificiran je omjer štete od kukaca od 16,38\% po hektaru. Pronađena je statistički značajna razlika između određenih klasa prema promjeru vezano za štetu od kukaca.

KLJUČNE RIJEČI: kukci potkornjaci, Ips sexdentatus, šteta, feromonski mamac, gustoća populacije 